\title{
Quality improvement in Cleaner Production aspect
}

\author{
Joanna Rosak-Szyrocka,* \\ ${ }^{1}$ Department of Production Engineering and Safety, Czestochowa University of Technology, Poland, \\ joanna.rosak-szyrocka@wz.pcz.pl
}

\begin{abstract}
The aim of the paper is presented the Cleaner Production (CP) issue in the aspect of the benefits that it gives the company in the competitiveness productivity and efficiency aspect. The research object is a company that is a leader in the Cleaner Production area - cement plant CEMEX. The research was based on a comparative analysis the company's sustainable development in 2008-2012. It was shown that substitution of alternative fuels (an increase of $43 \%$ in 2014 compared to 2010) and the construction the first world's alternative fuels dryer enabled not only for carbon dioxide reduction, but also hard coal consumption reduction and as a consequence allowed to relieve landfills waste. Thanks to elimination a part of the water contained in alternative fuels up to $8 \%$, the unit heat consumption in the clinker production process is reduced. This is due to avoiding evaporation of water at high temperatures. Analysis the presented data showed that the use of $\mathrm{CP}$ not only effectively protects the environment by reducing / minimizing waste streams, but also leads to increased profitability, productivity, efficiency and competitiveness of industry, which in turn leads to economic growth. The paper emphasizes that the CEMEX Rudniki cement plant has saved 132,000 Mg of carbon thanks to the use of alternative fuels over the last 5 years.
\end{abstract}

\section{Cleaner Production - literature review}

Cleaner Production (CP) is an environmental protection strategy based on continuous, integrated, preventive action in relation to processes, products and services, aimed at increasing production and service effectiveness and reducing risk for people and the natural environment [1]. The primary goal of Cleaner Production is to restructure the industry in an economically beneficial way, while improving the industry's environmental performance by reducing water and energy consumption, pollutant emissions and waste, while improving product quality and safety at the workplace. The foundation of Cleaner Production is the idea of sustainable development, i.e. the emphasis on preventing pollution at the source of their formation. CP emphasizes that it is important to apply good pro-ecological practices, the use of which may bring measurable benefits, including economic ones [2]:

\section{Less water, energy $=$ lower bills Less emissions to air $=$ less or no fees.}

\footnotetext{
*Corresponding author: joanna.rosak-szyrocka@wz.pcz.pl
} 
Authors [3] emphasize that Cleaner Production has a significant contribution to the reduction of environmental impact. Authors [4] emphasize that cleaner production, applied in a systemic manner, by means of an appropriate procedure, becomes a voluntary, informal environmental management system that allows any organization, regardless of its size and profile, to achieve in a short time measurable environmental and economic benefits and diversify your position on the market.

\section{Cleaner Production in the CEMEX company}

CEMEX is a leading manufacturer of cement, ready-mix concrete and aggregates in Poland. Chełm Cement Plant has been an active member of the Polish Cleaner Production Movement since 1997. CEMEX is a CP leader which means that not only fulfills all obligations resulting from environmental law and administrative decisions, but applies an appropriate system of responsible entrepreneurship principles and is successful in achieving particularly high production parameters while limiting emissions. CEMEX as a component of products uses process waste from other industries such as energy, metallurgy. These are wastes such as: slag, fly ash from coal combustion processes, fluid sands, which, in order to be introduced into the production process in a cement plant, are removed from landfills of industrial waste in the environment. Waste as alternative fuels (fraction of municipal and industrial waste properly processed and sorted) and sewage sludge can be safely burned in the production of clinker (instead of conventional fuels). Alternative fuels contain flammable fractions from renewable sources such as: paper, wood, rubber, natural textiles and are partly produced from municipal waste. The use of these wastes significantly reduces the impact of the company on the environment as it reduces the consumption of coal, and at the same time $\mathrm{CO}_{2}$ emissions from combustion processes and relieves the local municipal waste site. The Rudniki Cement Plant, up to 3 long rotary kilns currently in use (dry method) uses grinded solid waste (including municipal waste) in the amount of $8 \mathrm{Mg} /$ hour as a fuel, as well as dry sewage sludge. The use of rotary kilns by the plant enables the recovery of energy and the total utilization of waste, as these furnaces are considered to be the safest and state-of-the-art equipment used for co-firing. At the same time, high combustion temperatures ensure a significant reduction of harmful emissions in the process itself, which is described as waste-free, because the ash produced during the combustion of alternative fuels is permanently embedded in the clinker structure and becomes part of the product [5-7]. The CEMEX Rudniki company eliminated the unorganized emission due to the construction of the clinker silo. The reduction of the clinker index by reducing its share in produced cements and increasing additives (ie: fly ash, blast-furnace slag, limestone) is associated with a decrease in the unitary $\mathrm{CO}_{2}$ emission / tonne of the product. The plant aims to reduce the clinker index by increasing the production of cements with additives and by applying new solutions. The article analyzes the results of sustainable development in 2008-2010 and 2010-2014. The article also analyzes the situation of the company before the implementation of cleaner production and the implementation of the strategy of cleaner production. Table 1 presents the example of sustainable development in $2008-2010$.

Table 1. Sustainable development results in 2008-2010.

\begin{tabular}{|c|c|c|c|c|c|}
\hline \multicolumn{6}{|c|}{ GREENHOUSE GAS EMISSIONS } \\
\hline \multicolumn{6}{|c|}{ Issue of NOX compounds (in relation to limit values from the integrated permit) } \\
\hline \multicolumn{3}{|c|}{$\begin{array}{c}\text { Chelm }\left(\mathrm{mg} / \mathrm{Nm}^{3}\right) \\
\text { NOx }(800 \text { Limit } \text { NOx })\end{array}$} & \multicolumn{3}{|c|}{$\begin{array}{c}\text { Rudniki }\left(\mathrm{mg} / \mathrm{Nm}^{3}\right) \\
\text { NOx }(800 \text { Limit NOx) }\end{array}$} \\
\hline 2010 & 2011 & 2012 & 2010 & 2011 & 2012 \\
\hline 468 & 506 & 480 & 510 & 349 & 297 \\
\hline
\end{tabular}




\begin{tabular}{|c|c|c|c|c|c|c|c|c|}
\hline \multicolumn{9}{|c|}{ Emission of $\mathrm{SO}_{2}$ compounds (in relation to limit values from the integrated permit) } \\
\hline \multicolumn{5}{|c|}{$\begin{array}{l}\text { Chelm }\left(\mathrm{mg} / \mathrm{Nm}^{3}\right) \\
\mathrm{SO}_{2}\left(50 \text { Limit } \mathrm{SO}_{2}\right)\end{array}$} & \multicolumn{4}{|c|}{$\begin{array}{c}\text { Rudniki }\left(\mathbf{m g} / \mathbf{N m}^{\mathbf{3}}\right) \\
\text { Derogation from the limit in accordance with } \\
\text { the Regulation on emission standards for } \\
\text { installations }\end{array}$} \\
\hline \multicolumn{3}{|r|}{2011} & \multicolumn{2}{|c|}{2012} & 2010 & \multicolumn{2}{|r|}{2011} & 2012 \\
\hline 20 & & 13 & & 19 & 130 & & 93 & 98 \\
\hline \multicolumn{9}{|c|}{ Dust emission (in 1} \\
\hline \multicolumn{5}{|c|}{$\begin{array}{l}\text { Chelm }\left(\mathrm{mg} / \mathrm{Nm}^{3}\right) \\
\text { Dust limit } 30\end{array}$} & \multicolumn{4}{|c|}{$\begin{array}{l}\text { Rudniki }\left(\mathrm{mg} / \mathrm{Nm}^{3}\right) \\
\text { Dust limit } 30\end{array}$} \\
\hline \multicolumn{3}{|c|}{2011} & \multicolumn{2}{|c|}{2012} & 2010 & \multicolumn{2}{|r|}{2011} & 2012 \\
\hline 6 & & 6 & & 5 & 13 & & 5 & 10 \\
\hline \multicolumn{9}{|c|}{ AL I } \\
\hline \multicolumn{9}{|c|}{$\begin{array}{l}\text { Total net } \mathrm{CO}_{2} \text { emissions [thousand] tons] (in relation to the allocation of allowances in } \\
\text { accordance with the National Allocation Plan - } 1796 \mathrm{CO}_{2} \text { allocation) }\end{array}$} \\
\hline \multicolumn{5}{|c|}{ Chelm } & \multicolumn{4}{|c|}{ Rudniki } \\
\hline \multicolumn{2}{|c|}{2008} & 2009 & \multicolumn{2}{|c|}{2010} & 2011 & \multicolumn{2}{|r|}{2012} & 2008 \\
\hline \multicolumn{2}{|l|}{1093} & 1068 & \multicolumn{2}{|c|}{1239} & 1297 & \multicolumn{2}{|r|}{1035} & 445 \\
\hline \multicolumn{9}{|c|}{ WATER } \\
\hline \multicolumn{9}{|c|}{ Unit water consumption (liters / ton of cement) } \\
\hline \multicolumn{3}{|c|}{$\begin{array}{c}\text { Cement } \\
\text { (liters / ton of } \\
\text { cement) }\end{array}$} & Concrete & (liter / n & $a^{3}$ concrete) & & $\begin{array}{r}\text { ggregates } \\
\text { aggre }\end{array}$ & / ton of \\
\hline 2010 & 2011 & 2012 & 2010 & 2011 & 2012 & & 2010 & 2011 \\
\hline 216 & 181 & 182 & 185 & 174 & 175 & & 137 & 143 \\
\hline & & Use & of recycle & d water & or concrete & roduct & ion & \\
\hline & 2010 & & & 2011 & & & 20 & \\
\hline & $15.6 \%$ & & & $12.8 \%$ & & & 17. & \\
\hline & Subs & titution 0 & f alternat & ive fuels & in CEMEX & olska c & ement plan & \\
\hline & 2008 & & 2009 & & 2010 & & 2011 & 2012 \\
\hline & $34 \%$ & & $64 \%$ & & $69 \%$ & & $70 \%$ & $72 \%$ \\
\hline & & & & TERNA & TIVE FUEL & & & \\
\hline & & Hea & onsum & tion fro & n alternati & fuels (C & GJ) & \\
\hline & & 2011 & & & & & 2012 & \\
\hline & & $6.6 \cdot 10^{9}$ & & & & & $.4 \cdot 10^{6}$ & \\
\hline & Unita & y fuel co & nsumptio & n by the & CEMEX ow & fleet (I & iters / 1001 & \\
\hline & Cement & & & Concret & & & Aggreg & \\
\hline 2010 & 2011 & 2012 & 2010 & 2011 & 2012 & 2010 & 2011 & 2012 \\
\hline 32 & 32 & 33 & 62 & 63 & 62 & 34 & 33 & 32 \\
\hline & & & Indivi & lual ener & gy consum & & & \\
\hline CemeI & $\begin{array}{l}\text { it }(\mathrm{kWh} \\
\text { cement) }\end{array}$ & ton of & & $\begin{array}{r}\text { ncrete }(k \\
\text { concre }\end{array}$ & Wh/ & & $\begin{array}{l}\text { ggregates }( \\
\text { aggreg: }\end{array}$ & /tonę \\
\hline 2010 & 2011 & 2012 & 2010 & 2011 & 2012 & 2010 & 2011 & 2012 \\
\hline 124.5 & 124 & 125 & 3.4 & 2.9 & 3.2 & 5.8 & 6.2 & 5.6 \\
\hline
\end{tabular}

Table 2 presents sustainability results at CEMEX in 2010-2014. Table 3 shows Rudniki Cement Plant before and after CP implementation. 
Table 2. Sustainability results at CEMEX in 2010-2014.

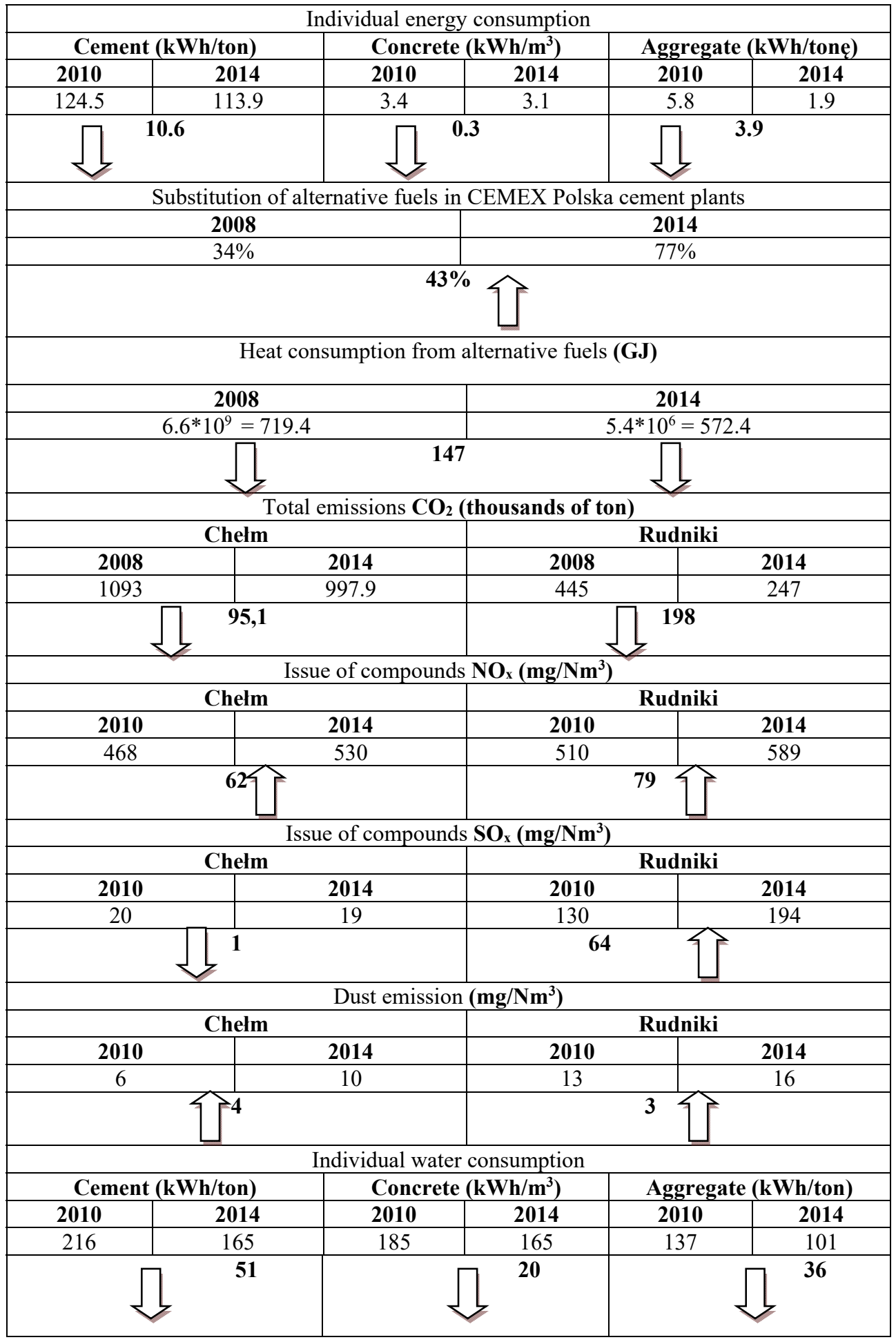


Table 3. Rudniki Cement Plant before and after CP implementation.

\begin{tabular}{|c|c|c|}
\hline $\begin{array}{l}\text { Before CP introduce } \\
2010 \\
\end{array}$ & $\begin{array}{l}\text { After CP introduce } \\
2011 \\
\end{array}$ & Difference \\
\hline \multicolumn{3}{|c|}{$\begin{array}{l}\text { Issue of } \mathrm{NO}_{\mathrm{X}} \text { compounds (in relation to limit values from the integrated permit) } \\
\left.\qquad\left(\mathbf{m g} / \mathbf{N m}^{3}\right) \mathbf{N O} \mathbf{( 8 0 0 L i m i t} \mathbf{N O}\right)\end{array}$} \\
\hline 510 & 349 & 161 \\
\hline \multicolumn{3}{|c|}{ Emission of $\mathrm{SO}_{2}$ compounds (in relation to limit values from the integrated permit) } \\
\hline 130 & 93 & 37 \\
\hline \multicolumn{3}{|c|}{ Dust emission (in relation to limit values from the integrated permit) } \\
\hline 13 & 5 & 6 \\
\hline
\end{tabular}

\section{Conclusion}

Analysis of issues related to Cleaner Production has shown that the use of CP not only effectively protects the environment by reducing or minimizing waste streams, but is also profitable because it leads to increased profitability, productivity (mainly by minimizing manufacturing costs) increasing the efficiency and competitiveness of industries that lead as a result of economic growth. Thanks to the use of alternative fuels, CEMEX Rudniki cement plant has saved $132,000 \mathrm{Mg}$ of carbon in the last 5 years. The ideal of a Cleaner Production strategy is waste-free production. In the current economic and technological situation enterprises can only look for different ways of waste management and use closed cycles of supply streams, eg water. This often leads to the integration of production lines, where waste from one line is used to supply material or energy to another production line. There may also be cooperation between entities under the so-called the supply chain. The reduction of pollutant emissions can be reduced by considering the entire life cycle of the product, paying attention to the materials used, water and energy flow, and the economic impact of switching to CP. Enterprises that decide to implement CP on a voluntary basis constantly strive to reduce pollution, reduce energy consumption and costs associated with environmental charges by developing and implementing so-called $\mathrm{CP}$ projects. The benefit of implementing CP projects is the limitation of the amount of fees for economic use of the environment, as well as the cessation of paying penalties for non-compliance with environmental conditions, if such penalties were imposed [7-13]. The use of CP as a tool for environmental management ensures that the objective in the field of environmental management becomes the most important environmental effect. ISO 14000 does not take into account the tools used, while CP provides them. The analysis of the data showed that in the plant in 2010-2014 the following environmental actions were carried out:

- Individual energy consumption: cement $10,6 \mathrm{kWh} /$ ton, concrete $0,3 \mathrm{kWh} / \mathrm{m} 3$, aggregate $3.9 \mathrm{kWh} /$ ton.

- Total $\mathrm{CO}_{2}$ emissions: Chełm, 95,1 thousand tons, Rudniki 198 thousand tons. Emissions of SOx compounds: reduction by $1 \mathrm{mg} / \mathrm{Nm}^{3}$.

- Unit water consumption: cement $51 \mathrm{kwh} /$ ton, concrete $20 \mathrm{kWh} / \mathrm{m}^{3}$, aggregate 36 $\mathrm{kWh} /$ ton.

\section{References}

1. S. Borkowski, R. Ulewicz, Zarzadzanie produkcja, Systemy produkcyjne (Oficyna Wydawnicza Humanitas, Sosnowiec, 2008)

2. B. Gajdzik, Problemy Ekologii, 11, 43, (2007) 
3. J. Lopes, M.D. Lima, A. Kiperstok, Journal of Cleaner Production, 170(1) (2018)

4. J. Boba, A. Saratowicz. Katalog produktów czystszej produkcji (Katowice, 2010)

5. A. Chmielarz, Czystsza Produkcja i Eko-zarządzanie, Cleaner Production \&Ecomanagement, 03 (2017)

6. E. Kardas, The Effect of Quality of Ferrous Burden Materials on the Quality of Pig Iron. METAL 2012, 21st International Conference on Metallurgy and Materials (Brno, 2012)

7. K. Jagieła, M. Gała, J. Rak, M. Kępiński, K. Szewczyk, Analysis of Electric Energy Quality in Arc Furnace System with Follow-Up SVC Compensation, EPQU 2009., 10th International Conference on Electrical Power Quality and Utilisation (Lodz, 2009)

8. J. Fresner, Journal of Cleaner Production, 6 (1998)

9. Ch. Hicks, R. Dietmar, Journal of Cleaner Production, 15 (2007)

10. Z. Nowak, M. J. Cichy, Phenomenological model of Cleaner Production (Springer, Netherlands, 2008)

11. L. Stone, Journal of Cleaner Production, 8 (2000)

12. A. Wiśniewska, Strategie proekologiczne $w$ zarządzaniu przedsiębiorstwem, $M$. Kistowski (red.), Studia ekologiczno-krajobrazowe $w$ programowaniu rozwoju zrównoważonego. Przegląd polskich doświadczeń u progu integracji z Unia Europejska, (2004)

13. R. Ulewicz R, Production Engineering Archives, 1/1 (2013) 